\title{
PENGEMBANGAN MODEL EKONOMI KREATIF BAGI MASYARAKAT DI DAERAH OBJEK WISATA BAHARI KABUPATEN KUPANG NUSA TENGGARA TIMUR
}

\author{
*(Ridolof W. Batilmurik ${ }^{1,}$ Hans A. Lao ${ }^{2}$ \\ Jurusan Administrasi Bisnis Politeknik Negeri Kupang, \\ Jl. Adi Sucipto Penfui Kupang \\ Email: rudy.morvin@gmail.com,Email:HansLao@gmail.com
}

\begin{abstract}
ABSTRAK
Salah satu potensi wisata yang terdapat di Kabupaten Kupang adalah objek wisata bahari. Terdapat begitu banyak potensi wisata bahari yang seharusnya menjadi tujuan wisata baik bagi turis mancanegar maupun domestic, namun pada kenyataannya potensi objek wisata bahari tersebut belum mampu dikelola secara baik tepat oleh pemerintah maupun masyarakat setempat. Pengelolaan potensi-potensi objek wisata bahari diharapkan mampu berkontribusi bagi peningkatan pendapatan asli daerah maupun untuk kesejahteraan masyarakat, khususnya di sekitar objek wisata bahari. Persoalan yang dihadapi adalah belum adanya model pengembangan objek wisata bahari secara tepat oleh pihak pemerintah daerah maupun masyarakat. Selain itu faktor inovatif dan kreatif dari masyarakat maupun pemerintah daerah juga diduga menjadi penyebab sehingga potensi objek wisata bahari belum dikelola secara optimal dalam rangka meningkatkan kesejahteraan masyarakat. Objek wisata bahari seperti Pantai Salupu, Airsina, Manikin, Batu Lesa, dan Tablolong memiliki objek wisata yang sangat indah, namun karena pengelolaan yang belum tepat maka objek wisata bahari tersebut tidak mampu memberikan kontribusi bagi peningkatan ekonomi masyarakat setempat. Berawal dari observasi dan wawancara yang dilakukan pelaku usaha dengan Kadin. UMKM dan Koperasi serta Kadin. Pariwisata dan Kebudayaan Kabupaten Kupang ditemui berbagai persoalan, diantaranya: kurangnya modal usaha, kualitas sumber daya manusia masyarakat serta tidak adanya kerja sama dengan pihak perbankan dan investor menjadi kendala dalam pengembangan ekonomi kreatif bagi peningkatan ekonomi masyarakat setempat. Penelitian ini bertujuan untuk mendapatkan model pengembangan ekonomi kreatif yang tepat sehingga diharapkan mampu meningkatkan ekonomi masyarakat yang berada di objek wisata bahari tersebut. Selain itu juga diharapkan model pengembangan ini dapat diterapkan oleh Pemerintah Kabupaten Kupang dan pihak terkait sehingga mampu meningkatkan kunjungan wisawatan sehingga berdampak kepada peningkatan ekonomi masyarakat. Penelitian ini dilakuan melalui 2 tahap ; (1) pembuatan model pengembangan ekonomi kreatif dan (2) uji coba pengembangan model. Dengan waktu berjalan, pembuatan dan pengembangan model ekonomi kreatif tahap identifikasi potensi dan hambatan dalam pelaksanaan model ini. Tahapan ini memerlukan partisipasi dari pihak Pemerintah Kabupaten Kupang melalui Dinas Pariwisata dan Kebudayaan serta Dinas UMKM Kabupaten Kupang begitu juga dukungan dari masyarakat di sekitar objek wisata bahari. Dengan demikian pengembangan model ini dapat meningkatkan kemampuan dari masyarakat dan pemerintah setempat.
\end{abstract}

Kata Kunci: Pengembangan Model, Objek Wisata Bahari, Potensi Wisata 


\section{PENDAHULUAN}

Salah satu kabupaten di Propinsi NTT yang turut berbenah dalam pengembangan potensi wisata adalah Pemerintah Kabupaten Kupang melalui Dinas Kebudayaan dan Pariwisatanya melakukan upaya untuk terus meningkatkan kesejahteraan masyarakatnya melalui upaya peningkatan ekonomi kreatif masyarakat yang berada di daerahdaerah yang memiliki potensi wisata. Salahsatu perhatian Pemerintah Kabupaten Kupang terhadap banyaknya jenis objek wisata yang ada adalah jenis objek wisata bahari yang diharapkan mampu membawah kesejahteraan bagi masyarakat sekitarnya.

Potensi objek wisata bahari yang dimiliki oleh Pemerintah Kabupaten Kupang perlu mendapat perhatian dan dukungan pemerintah kabupaten agar dikelola secara baik sehingga mendatangkan pendapatan asli daerah dan hasilnya bisa dirasakan oleh masyarakat di sekitar daerah objek wisata tersebut. Kondisi yang ada hingga kini memperlihatkan bahwa belum adanya pengelolaan secara optimal.

Permasalahan yang dihadapi oleh pemerintah daerah turut dirasakan oleh masyarakat kabupaten yang boleh dikatakan hidup dalam tingkat perekonomian yang rendah. Jika saja perhatian pemerintah untuk mengembangkan potensi wisata bahari tentu akan berdampak kepada perubahan pola pikir masyarakat yang sangat menggantungkan hidup pada profesi mereka sebagai petani/peladang dan peternak. Dengan memberdayakan masyarakat di sekitar objek wisata bahari yang ada, pemerintah diharapkan mampu meningkatkan taraf hidup masyarakat kearah yang lebih baik.

Perhatian pemerintah dengan memberdayakan masyarakat di sekitar objek wisata bahari hendaknya memberikan manfaat langsung kepada masyarakat dalam hal pengembangan ekonomi kreatif (eko-wisata). Kondisi ini harus disikapi oleh pemerintah dan seluruh masyarakat, khususnya masyarakat di sekitar objek wisata bahari dengan memberikan bantuan berupa informasi dan modal; berupa pelatihan mengenai kewirausahaan lentrepreneurship, modal usaha agar masyarakat mampu untuk meningkatkan taraf hidup mereka dan sekaligus merubah mindsett untuk tidak menggantungkan hidup pada sektor pertanian/perkebunan.

Untuk mengatasi masalah-masalah yang dihadapi masyarakat disekitar objek wisata bahari di Kabupaten Kupang dimana diperhadapkan dengan taraf ekonomi yang rendah, kemiskinan, tingkat pendidikan yang rendah, diperlukan perhatian, kerjasama dari semua pihak, baik pemerintah daerah, masyarakat dan lembaga pendidikan yakni Perguran Tinggi untuk memberikan solusi yang tepat untuk mengatasinya. Salah satunya solusi yang dapat diberikan adalah dengan melakukan program "Pengembangan Ekonomi Kreatif" bagi masyarakat di daerah objek wisata bahari yang ada.

Pengembangan ekonomi kreatif yang dimaksudkan sebagai upaya memberikan keterampilan bagi masyarakat untuk mampu menciptakan lapangan kerja untuk diri sendiri dan orang lain secara ekonomis dengan menciptakan ide-ide kreatif dengan semua potensi wisata yang ada. Pengembangan ini dimaksudkan sebagai upaya agar masyarakat mampu memenuhi kebutuhan hidupnya dengan memiliki sumber penghasilan lain yang berasal dari objek wisata yang ada.

Tujuan dari penelitian ini adalah 
1. Untuk mengetahui bagaimanakah kondisi objek wisata bahari di Kabupaten Kupang

2. Untuk mengetahui bagaimanakah profil masyarakat di daerah objek wisata bahari di Kabupaten Kupang

3. Untuk mengetahui bagaimanakah model pengembangan ekonomi kreatif sehingga memiliki nilai jual

4. Untuk mengetahui bagaimanakah melakukan sinerji khususnya program-program pengembangan ekonomi kreaktif yang sesuai dengan kebutuhan pariwisata saat ini

Pariwisata diartikan sebagai seluruh kegiatan orang yang melakukan perjalanan ke dan tinggal di suatu tempat di luar lingkungan kesehariannya untuk jangka waktu tidak lebih dari setahun untuk bersantai (leisure), bisnis dan berbagai maksud lain. Dalam paradigma lama, pariwisata yang lebih mengutamakan pariwisata masal, yaitu yang bercirikan jumlah wisatawan yang besar/berkelompok dan paket wisata yang seragam dan sekarang telah bergerak menjadi pariwisata baru, yaitu wisatawan yang lebih canggih, berpengalaman dan mandiri, yang bertujuan tunggal mencari liburan fleksibel, keragaman dan minat khusus pada lingkungan alam dan pengalaman asli. Dalam usaha pengembangannya Indonesia wajib memperhatikan dampak-dampak yang ditimbulkannya, sehingga yang paling tepat dikembangkan adalah sektor ekowisata dan pariwisata alternatif yang oleh Eadington dan Smith (1995) diartikan sebagai konsisten dengan nilai-nilai alam, sosial dan masyarakat yang memungkinkan adanya interaksi positif diantara para pelakunya.

\section{Ekonomi Kreatif}

Pariwisata di Indonesia menurut UU Kepariwisataan No. 9 Tahun 1990 pasal 1 (5) adalah segala sesuatu yang berhubungan dengan wisata serta usaha-usaha yang terkait di bidangnya. Indonesia memiliki sumber daya wisata yang amat kaya dengan aset alam, budaya, flora dan fauna dengan ciri khas Asia dan Australia di setiap wilayah perairan dan pulau di Indonesia (Gunawan M.P., 1997).

Pariwisata mempuyai peranan yang positif, dengan meningkatkan kegiatan ekonomi dan seni budaya serta meningkatkan taraf hidup masyarakat. Selain itu juga dapat meningkatkan rangsangan yang berupa pemeliharaan terhadap peninggalan sejarah, hutan suaka dan lain sebagainya. Untuk itulah perlu untuk dijaga dan dikembangkan agar tidak terjadi kerusakan lingkungan hidup. Hal tersebut dapat di atasi dengan beberapa pendekatan di antaranya :

1. Perubahan persepsi tentang pariwisata

Pariwisata harus dipersepsikan sebagai suatu alat atau instrument untuk meningkatkan kualitas hubungan antar manusia ( masyarakat lokal ) dan kualitas lingkungan hidup.

2. Kritera-kriteria pengembangan pariwisata

Untuk memberikan arahan yang lebih jelas tentang pengembangan pariwisata perlu ditetapkan beberapa kriteria yang beriorientasi pada pemberdayaan masyarakat setempat.

3. Pengembangan pariwisata perlu dijadikan sebagai bagian dari pembangunan nasional yang berkelanjutan. (Gamal Suwnatoro; 2001, 80-81)

\section{Pariwisata dan Ekonomi Daerah}


Pengembangan ekonomi lokal merupakan suatu konsep pembangunan ekonomi yang mendasarkan pada pendayagunaan sumber daya lokal yang ada pada suatu masyarakat, sumber daya manusia, sumber daya alam, dan sumber daya kelembagaan. Pendayagunaan sumberdaya tersebut dilakukan oleh masyarakat itu sendiri bersama pemerntah lokal maupun kelompokkelompok kelembagaan berbasis masyarakat yang ada. Untuk mencapai tujuan tersebut, pemerintah daerah dan masyarakatnya harus secara bersamasama mengambil inisiatif dalam pengembangan ekonomi local yang dapat dilakukan melalui suatu forum kemitraan. Sedangkan kemitraan itu sendiri mempunyain makna bahwa dalam tataran proses perencanaan, pelaksanaan dan evaluasi program ada kebersamaan yang sinergis antara pemerintah, dunia usaha dan mayarakat.

Perhatian terhadap pariwisata sudah sangat mulus tersebar karena sadar akan manfaat-manfaat yang didatangkan bagi negara-negara penerima wisatawan:

- Bahwa pariwisata menjadi sumber pendapatan valuta asing dengan menjual jasa-jasa dan barangbarang yang berkaitan dengan pariwisata. Bahwa pendapatan ini mengalir cepat dan langsung terbagi-bagi secara meluas kepariwisataan dalam perekonomian nasional, sehingga mampu membagi- bagi laju pendapatan secara meluas, bertambah banyak dan berputarputar ke segala lapisan pedagang besar dan pengecer, transportasi, beragam komponen sektor pariwisata, kebutuhan-kebutuhan dan usaha yang berdasarkan tingkat pengeluaran konsumen.

- Bahwa pariwisata adalah suatu pasaran lanjutan searah dengan meningkatnya yang begitu pesat tingkat pendapatan keluarga yang tidak habis terpakai, khusunya pada negara-negara yang industrinya sudah maju. khusunya pada negaranegara yang industrinya sudah maju.

- Bahwa industri pariwisata jika dibanding dengan industri lain termasuk industri yang investasi modalnya kecil sebanding dengan arus pendapatan yang mungkin.

- Bahwa pariwisata menyediakan suatu pasaran ekspor tempat konsumen datang untuk meneliti produk-produk tersebut.

- Bahwa produk yang dijual terutama berupa jasa-jasa dan tidak dapat dijamah karena udara yang sejuk, alam yang indah terdapat tempattempat yang secaar potensial tidak akn habis-habisnya, dan hanya tunduk pada keterbatasan upaya promosi dan penjualan

- Bahwa pariwisata adalah sarana yang ampuh dan efektif bagi kebijakan umum untuk menciptakan perpaduan social dan budaya pada tingkat nasional maupun internasional, untuk mengembangkan industri-industri lain dan sarana pemupukan tenggang rasa dan saling pengertian dengan negara-negara tetangga dan dunia umumnya

Wisata bahari merupakan suatu bentuk wisata potensial termasuk di dalam kegiatan "Clean industry" pelaksanaan wisata bahari yang berhasil apabila memenuhi berbagai komponen yakni terkaitnya dengan kelestarian lingkungan alami, kesejahteraan penduduk yang mendiami wilayah tersebut, kepuasan pengunjung yang menikmatinya dan keterpaduan komunitas dengan area pengunjung yang menikmatinya dan keterpaduan komunitas dengan area pengembangannya(Siti Nurisyah, 1998). Dengan memperhatikan komponen 
tersebut maka wisata bahari akan memberikan kontribusi nyata bagi perekonomian masyarakat.

\section{METODE PENELITIAN DAN PEMBAHASAN \\ Jenis Penelitian}

Penelitian ini berjenis penelitian dan pengembangan (Research \& Development), yaitu suatu metode penelitian yang bertujuan untuk menghasilkan produk tertentu dan menguji keefektifan produk tersebut (Sugiyono, 2008). Kemudian menurut Sukmadinata (2007), "Penelitian dan pengembangan bertujuan untuk mengembangkan suatu produk baru atau menyempurnakan produk yang telah ada, yang dapat dipertanggungjawabkan. Produk tersebut tidak selalu berbentuk hardware, seperti buku, modul, alat bantu pembelajaran, tetapi juga dapat berbentuk software, seperti program komputer, pembelajaran di kelas, ataupun model-model kebijakan/strategi/sistem".

\section{Model Penelitian Pengembangan}

Penelitian ini difokuskan pada model pengembangan ekonomi kreatif bagi masyarakat di daerah wisata bahari di Kabupaten Kupang agar memiliki nilai jual dan sinergitas dengan program pengembangan ekonomi kreatif sesuai kebutuhan. Metode yang digunakan dalam penelitian ini adalah metode kualitatif dengan menggunakan pendekatan studi kasus mengenai strategi pengembangan ekonomi kreatif di Kabupaten Kupang.

$$
\begin{aligned}
& \text { Langkah-langkah } \\
& \text { prosedur yang ditempuh dalam } \\
& \text { pelaksanaan penelitian ini dapat } \\
& \text { dilihat dalam bentuk alur pada } \\
& \text { gambar di bawah ini. }
\end{aligned}
$$

Gambar 1 Bagan alir Penelitian

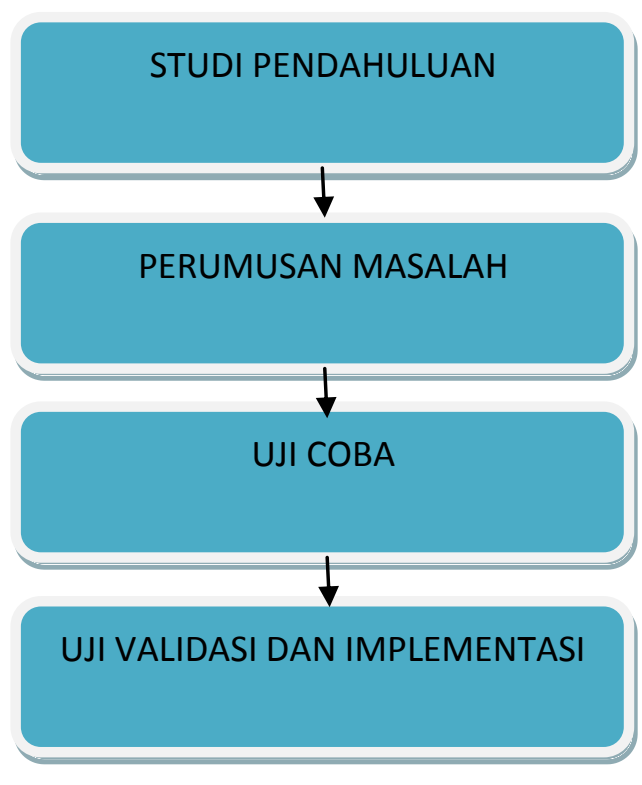

\section{HASIL PENELITIAN DAN PEMBAHASAN \\ Profil Objek Wisata Bahari \\ Kabupaten Kupang}

a) Pantai Tablolong

Pantai yang terletak di Kecamatan Kupang Barat ini memiliki pasir putih yang indah dan berjarak kurang lebih $30 \mathrm{Km}$ dari Kota Kupang, namun akses jalan menuju ke lokasi pantai ini dalam kondisi yang kurang baik. Di sekitar pantai terdapat perkampungan nelayan, dan merupakan tempat budidaya rumput laut dan tempat pendaratan sementara hasil tangkapan nelayan setempat. Selain berprofesi sebagai nelayan, dengan adanya objek wisata panatai ini, masyarakat pesisir setempat juga mendapatkan penghasilan dengan jalan menjual barang dagangan di lokasi pantai diataranya; usaha ikan bakar, usah kios dan warung makan. Didalam lokasi objek wisata 
bahari terdapat 2 orang pedagang tetap yang berjualan, terdapat 1 usaha akomodasi milik warga local yang sementara dalam pembangunan dan 1 cottage milik warga local yang bersuamikan orang asing berkebangsaan Inggris.

\section{b) Pantai Oesina}

Pantai dengan Pasir putih dan air laut yang jernih dan tenang menjadi daya tarik tersendiri dari pantai yang elok ini. Pantai ini belum banyak dikunjungi karena akses jalan yang tidak begitu baik. Nama Pantai Air Cina sebenarnya adalah Air Sina yang diberi nama oleh Orang Rote yang mendiami tempat ini. Pantai ini diberi nama Air Sina karena dahulu para Pedagang Portugis menggunkan tempat ini sebagai tempat berlabuh. Pantai ini juga merupakan tempat para nelayan dan petani rumput laut menggantungkan hidup.. Rumput laut yang dipanen dikeringkan diatas para-para yang ada dipinggiran pantai. Rumput laut yang dikeringkan kemudian ditimbang. Terdapat juga usaha garam tradisional milik warga local yang menggunakan kulit kerang yang diproduksi kemudian dipasarkan ke pasar-pasar local guna menambah pendapatan rumah tangga.

Untuk mencapai pantai ini diperluhkan waktu sekitar 1 jam dari Kota Kupang, sebelum pantai Tablolong. Tepat di cabang Sekolah Dasar Nefo belok kiri, kemudian menempuh jalan sekitar 30 menit. Pantai ini belum dikelola menjadi tempat wisata sehingga kita perluh membawa makanan dan minuman.

\section{c) Pantai Salupu}

Karena keunikan pasirnya yang berwarna coklat kehitaman serta objek wisata masih belum terjamah oleh wisatawan. Adapun untuk melihat keunikan pasir ini harus menunggu hingga air surut. Ini adalah lanjutan dari pantai Batu Lesa, yg terletak di Desa Lifuleo. Jika anda berkunjung dari arah kupang menunju Tablolong. Saat melewati 2 tower belok kanan (Jalur evakuasi) lurus hingga menemukan cabang tepat di Posyandu Tuadale belok kananmelewati hutan dengan jalan bebatuan dan tanah putih.

\section{d) Pantai Batu Lesa}

Pantai ini tergolong pantai selatan yang terkenal dengan ombaknya yang keras. Pantai ini masih tergolong alami. Pantai ini memiliki garis pantai yang cukup panjang sehingga selama perjalanan dari sisi kanan jalan kita bisa langsung menikmati pemandangan laut. Ada bagian dari pantai yang terbuka untuk umum dan ada juga yang di kelola oleh warga sekitar sehingga kita harus membayar karcis masuk. Untuk bagian yang harus membayar karcis ada batu yang cukup besar di pingggir pantai yang diatasnya terdapat 3 Salib. Bagian pantai ini ada yang berpasir dan ada yang berbatuan kecil. Di objek lokasi pantai ini belum ada usaha dari masyarakat setempat untuk berjualan di di daerah pantai. Masyarakat masih terfokus pada usaha penjualan pasir dan batu 
kelikir serta menjadi nelayan tradisional.

\section{e) Pantai Manikin}

Pantai satu ini memiliki keistimewaan tersendiri karena saat pantai surut, bukan pasir yang kita temui sebaliknya mata kita akan di hadapkan pada banyaknya batu koral bercampur bongkahan batu akik menghampar di garis pantai dengan panjang sekitar tiga kilometer. Dibibir pantai banyak di tumbuhi oleh pohon duri sehingga sangat cocok untuk berteduh dan menikmati panorama pantai. Pantai ini banyak dikunjungi oleh warga sekitar kota dan kabupaten Kupang, karena letaknya yang tidak jauh dari Kota Kupang. Saat sore hari atau liburan banyak warga yang berkunjung entah untuk menikmati pantai, mandi atau menikmati sunset. Dipantai ini ada juga beberapa lopo sebagai temapt berteduh. Pepohonan yang ada dibibir pantai sering dijadikan objek Foto untuk keperluan pribadi atau pernikahan. Saat hari minggu atau hari libur ada penjual yang menjajakan makanan ringan, Kelapa Muda, dll.

\section{Strategi Pengembangan Ekonomi Kreatif di Kabupaten Kupang \\ 1) Temuan Penelitian}

Setelah penulis melakukan penelitian di Kabupaten Kupang melalui observasi secara langsung dan wawancara dengan beberapa informan serta melakukan studi pustaka dari beberapa literatur yang berhubungan dengan ekonomi kreatif, maka penulis berhasil memperoleh data yang berhubungan dengan masalah yang diteliti. Berdasarkan data yang diperoleh langsung pada lokasi penelitian, maka dalam bab ini penulis akan memaparkan sejumlah hasil penelitian tentang Strategi Pengembangan Model Ekonomi Kreatif di objek wisata bahari Kabupaten Kupang seperti yang diuraikan di bawah ini :

\section{a. Strategi Pengembangan}

Ekonomi Kreatif di Objek Wisata Bahari Kabupaten Kupang

Upaya meningkatkan ekonomi kreatif di Kabupaten Kupang, maka dipandang perlu untuk pihak pemerintah melaksanakan beberapa strategi pengembangan ekonomi kreatif di bawah ini:

Strategi Pertama Perubahan Sistem Birokrasi

Dalam pengembangan kawasan objek wisata bahari, pemerintah Kabupaten Kupang merubah sistem birokrasi serta mengubah regulasi dan kebijakan untuk mempermudah masuknya investor yang berminat untuk mengembangkan objek wisata bahari yang ada sehingga turut meningkatkan kesempatan bagi penduduk daerah pesisir pantai untuk meningkatkan pendapatan rumah tangganya.

Strategi Ke dua (II) Pemetaan Sumber Daya Ekonomi Kreatif Yang Bisa Dimanfaatkan

Pemerintah Kabupaten Kupang melalui dinas teknis yang berkaitan perlu untuk melakukan pemetaan terhadap potensi-potensi sumber daya ekonomi kreatif di objek wisata 
bahari di Kabupaten Kupang yang ditemukan pada saat riset melalui observasi dan wawancara yang dilakukan pada tokoh masyarakat dan pedagang, diantaranya: pengolahan Rumput laut, pengolahan hasil tangkapan ikan nelayan tradisional, penangkaran ikan/bandeng, pengolahan garam tradisional, usaha penyewaan perahu, kerajinan kulit kerang dan koral.

\section{Strategi Ketiga (III) Penyusunan Rencana Pengembangan}

Pemerintah Kabupaten

Kupang melalui dinas terkait dan akademisi (Dosen Politeknik Negeri Kupang) memberikan pelatihanpelatihan teknis untuk meningkatkan nilai ekonomis tentang pengolahan rumput laut, pengolahan hasil tangkapan ikan nelayan tradisional, penangkaran ikan/bandeng, pengolahan garam tradisional, usaha penyewaan perahu, kerajinan kulit kerang dan koral.

Strategi Ke empat (IV) Menciptakan Kualitas SDM Pelaku Eknomi Kreatif

Pemerintah Kabupaten Kupang melalui dinas terkait dan akademisi (Dosen Politeknik Negeri Kupang) memberikan pelatihanpelatihan manajemen untuk meningkatkan kualitas sumber daya manusia (pelaku ekonomi kreatif) di bidang pemasaran, pengelolaan keuangan, motivasi dengan tujuan agar pelaku ekonomi mampu berpikir produktif, kreatif dan inovatif.

Strategi Ke lima (V) Penciptaan Pasar Bagi Produk Ekonomi Kreatif

Pemerintah Kabupaten melalui dinas terkait perlu melakukan promosi produk ekonomi kreatif melalui media massa local maupun nasional baik berupa media cetak maupun media digital sesuai dengan perkembangan jaman. Pemerintah Kabupaten Kupang perlu berupaya menyelenggarakan event-event di objek wisata bahari secara berkesinambungan untuk meningkatkan kunjungan wisata yang pada akhirnya berdmapak pada peningkatan penjualan produk ekonomi kreatif, pemerintah perlu menyiapkantempat khusus untuk penjualan produk-produk ekonomi kreatif darti masyarakat maupun unit usaha di daerah objek wisata bahari.

b. Model Pengembangan Ekonomi Kreatif di Objek Wisata Bahari Kabupaten Kupang.

Berdasarkan riset yang telah dilakukan ditemukan bahwa kondisi pelaku ekonomi kreatif yang ada di objek wisata bahari di Kabupaten Kupang belum mendapat perhatian yang serius dari pemerintah Kabupaten Kupang. Hal ini dibuktikan dengan keadaan fasilitas penunjang di objek wisata yang kurang mendukung, banyak fasiltas pendukung yang tidak terawat (rusak) dan pelaku ekonomi kreatif yang berusaha 
dengan kemampuan sendiri dalam membangun tempat usahanya dan tanpa bantuan dari perbankan dalam meningkatkan modal usahanya. Selain itu, di objek wisata bahari belum ada investor yang mengembangkan objek wisata tersebut.

Hal ini menunjukan tidak adanya sinergitas antara pemerintah, investor, perbankan dan pelaku usaha (masyarakat pesisir objek wisata). Sehingga melalui riset ini, dapat ditawarkan sebuah model pengembangan ekonomi kreatif yang diharapkan mampu menjadi solusi terhadap permasalahan di objek wisata bahari Kabupaten Kupang.

Adapun model pengembangan ekonomi kreatif di objek wisata bahari Kabupaten Kupang yang dapat ditawarkan adalah Model Kerja Sama dalam pengembangan ekonomi kreatif pada kawasan objek wisata bahari. Dalam model ini pihakpihak yang terkait menjalin kerja sama dengan melakukan kontrak kerja baik dalam penyediaan sarana dan prasarana maupun jaminan pemasaran produk ekonomi kreatif di objek wisata bahari.

Peran dan fungsi pihakpihak yang terlibat dalam kerja sama:

\section{(1). Pihak Pemerintah}

Pemerintah

Kabupaten Kupang dalam rangka mengembangkan sector ekonomi kreatif di objek wisata bahari juga mempunyai fungsi dan peran penting dalam memanfaatkan seoptimal mungkin potensi daerahnya yaitu sebagai pelaksana sekaligus penanggung jawab terhadap pembangunan pariwisata. Hal ini sejalan dengan pendapat yang dikemukakan oleh Pendit (1994;56) yang menyatakan bahwa fungsi pemerintah daerah khususnya di sector pariwisata adalah:

- Sebagai pelaksana dan penanggung jawab penuh terhadap segala kegiatan pariwisata dan pembangunan

kepariwisataan di daerahnya serta hal-hal lain yang terkait dengan urusan kepariwisataan.

- Sebagai pelaksana dan penaggung jawab dari upaya-upaya pengembangan potensi pariwisata yang ditugaskan kepadanya oleh pemerintah pusat dan atau pemerintah daerah tingkat atasnya menurut asas tugas pembantuan.

Dalam rangka memajukan ekonomi kreatif di objek wisata bahari Pemerintah Kabupaten Kupang perlu mengeluarkan peraturan daerah/perda tentang kerja sama pemerintah dalam pembanggunan,

pengembangan dan pengelolaan objek wisata bahari yang ada. Sehingga melalui perda yang dibuat, 


$$
\begin{aligned}
& \text { pemerintah bisa } \\
& \text { mendelegasikan kepada } \\
& \text { dinas teknis tertentu untuk } \\
& \text { melaksanakan fungsi } \\
& \text { sebagai regulator dan } \\
& \text { innovator dalam proses } \\
& \text { kerja sama yang di } \\
& \text { maksud. } \\
& \text { Diharapkan dengan } \\
& \text { adanya peraturan daerah } \\
& \text { yang dibuat mampu } \\
& \text { menjadi acuan hokum bagi } \\
& \text { pelaksanaan } \\
& \text { pengembangan ekonomi } \\
& \text { kreatif di kawasan objek } \\
& \text { wisata bahari di } \\
& \text { Kabupaten Kupang. } \\
& \text { Pemerintah Kabupaten } \\
& \text { Kupang diharapkan } \\
& \text { mampu menciptakan } \\
& \text { sebuah iklim yang } \\
& \text { kondusif bagi investor } \\
& \text { untuk menanamkan modal } \\
& \text { dalam pengembangan } \\
& \text { ekonomi kreatif pada } \\
& \text { objek wisata bahari di } \\
& \text { Kabupaten Kupang. Acuan }
\end{aligned}
$$

\section{(2). Pihak Investor}

Terkait keterlibatan pihak investor dalam pengembangan ekonomi kreatif di kawasan objek wisata bahari di Kabupaten Kupang memiliki beberapa alasan, diantarannya:

$$
\begin{array}{lr}
\text { - Sebagai } & \text { alternative } \\
\text { untuk } & \text { menyelesaikan } \\
\text { masalah } & \text { keterbatasan }
\end{array}
$$

sumber daya yang dimiliki pemerintah yakni anggaran pemerintah dalam pengembangan ekonomi kreatif di objek wisata bahari tersebut sementara tuntutan masyarakat terhadap ekonomi kreatif semakin lama semakin meningkat

- Keterlibatan sector pariwisata dalam kerja sama pembangunan kawasan wisata bahari adalah merupakan wujud peningkatan peran investor

- Keterlibatan investor bisa meningkatkan transparansi dan peningkatan kualitas. Keterlibatan

investor sebagai alternative

menyelesaikan masalah keterbatasan sumber daya yang dimiliki pemerintah daerah. Hal ini berimplikasi pada pembangunan yang kerdil bagi sector wisata, minimnya sarana dan prasarana serta pengelolaan manajemen yang buruk. Pihak investor diharapkan mampu menanamkan modalnya untuk memperkuat kelemahan yang ditinggalkan oleh pemerintah daerah.

Dalam model kerja sama ini peranan investor ialah menyediakan modal untuk membangun kawasan objek wisata bahari. Pihak pemerintah 


$\begin{array}{lr}\text { daerah } & \text { hanya } \\ \text { menyediakan } & \text { lahan. } \\ \text { Pihak investor juga } & \text { untuk } \\ \text { berperan } & \text { dan } \\ \text { mengoperasikan } & \text { mengelola manajemen. }\end{array}$

\section{(3). Pihak Masyarakat} (Pelaku Ekonomi Kreatif)

Pengembangan

ekonomi kreatif di objek wisata bahari tidak dapat berjalan dengan baik tanpa adanya peran serta pihak lain, manfaat yang optimal hanya tercapai bila pertumbuhannya selaras dengan usaha pemeliharaan dan pengembangan sector lain. Dalam hal ini masyarakat merupakan salah satu unsure pelaku yang dapat mendukung tercapainya satu (1) hasil yang optimal tersebut. Oleh karena itu peran serta pelaku ekonomi kreatif sangat dibutuhkan baik secara langsung ataupun tidak.

Pemberdayaan

pelaku ekonomi kreatif lebih menitik beratkan pada peningkatan kemampuan masyarakat loka di sekitar objek wisata bahari dalam pengembangan ekonomi kreatif. Peran serta masyarakat baik secara langsung/tidak dapat dilakukan baik secara perorangan/kelompok dengan segala kemampuan produktif, inovatif dan kreatif sehingga diharapkan dapat membantu

$\begin{array}{lr}\text { pemerintah } & \text { dalam } \\ \text { mengembangakan } & \\ \text { potensi-potensi } & \text { yang } \\ \text { dimiliki oleh } & \text { objek } \\ \text { wisata bahari } & \text { di } \\ \text { Kabupaten } & \text { Kupang } \\ \text { tersebut. } & \end{array}$

(4). Pihak Perbankan

Keterlibatan pihak perbankan dalam model pengembangan ekonomi kreatif di objek wisata bahari Kabupaten Kupang tentu sangat diharapkan. Hal ini mempermudah masuknya investasi dari swasta yang akan meningkatkan ekonomi di kawasan objek wisata bahari dengan jalan kemudahan mendapatkan pinjaman dengan suku bunga yang terjangkau. Bukan saja bagi pihak investor tetapi juga bagi masyarakat (pelaku) ekonomi kreatif. Sehingga perlu dibangun kerja sama antara pemerintah daerah dengan pihak perbankan.

Faktor Pendukung dan Hambatan Pengembangan Ekonomi Kreatif Pada

Objek Wisata Bahari di Kabupaten Kupang.

Dalam pengembangan ekonomi kreatif di objek wisata bahari, terdapat faktor pendukung dan penghambat yang mempengaruhi strategi pengembangannya di Kabupaten Kupang. Dari observasi dan wawancara yang telah dilakukan oleh peneliti maka hasil analisis adalah sebagai berikut : 
a) Faktor pendukung

1) Terdapat Banyak Objek Wisata Bahari di Kabupaten Kupang.

Dengan banyaknya jumlah objek wisata bahari di Kabupaten Kupang, maka jumlah pelaku ekonomi kreatif bisa memanfaatkan potensipotensi yang dimiliki objek wisata dimaksud dapat bertambah, hal ini juga akan meningkatkan minat kunjungan wisatawan yang berdampak kepada peningkatan ekonomi masyarakat setempat.

2). Banyak Potensi-Potensi Ekonomi Kreatif

Terdapat potensi-potensi dari setiap objek wisata bahari berupa pengolahan rumput laut, pengolahan hasil tangkapan ikan nelayan tradisional, penangkaran ikan/bandeng, pengolahan garam tradisional, usaha penyewaan perahu, kerajinan kulit kerang dan koral yang dapat dikelola untuk peningkatan ekonomi masyarakat setempat.

3) Adanya Dukungan dari Pemerintah Daerah

Pemerintah Kabupaten Kupang melalui dinas teknis terkait telah melakukan beberapa kegiatan dalam mendukung pengembangan objek wisata di Kabupaten Kupang dengan membuat penunjuk jalan serta fasilitas fisik di lokasi wisata serta mempromosikan lewat media local/nasional melalui media digital seperti media sosial dan website, baliho dan brosur.

4) Pengoptimalan Teknologi Informasi
Dalam pengembangan objek wisata bahari di Kabupaten Kupang, Pemerintah Kabupaten Kupang telah memanfaatkan teknologi informasi untuk mempromosikan keberadaan objek wisata bahari melalui website resmi Dinas Pariwisata Kabupaten Kupang (www.dinas pariwisata dan kebudayaan kabupaten kupang)

5) Adanya Transportasi Darat/Laut Dan Udara

Tersedianya semua sarana transporasi dari dank e objek wisata bahari di Kabupaten Kupang.

\section{b) Faktor penghambat}

1) Kurangnya Kerja Sama $\begin{array}{rr}\text { Kurangnya } & \text { kerja sama } \\ \text { antara semua } & \text { pelaku, baik } \\ \text { pemerintah } & \text { Kabupaten }\end{array}$ Kupang, pihak investor, pihak masyarakat di kawasan objek wisata bahari dan pihak perbankan. Sebagai contoh, adanya objek wisata yang sudah dibangun sarana dan prasarananya tetapi tidak memberikan kontribusi pada pendapatan daerah diakbiatkan karena tidak adanya karcis masuk.

2). Fasilitas dan Infrastruktur Masih Kurang Dan Tidak Terawat Fasilitas dan infrastruktur pariwisata yang ada di beberapa objek wisata di Kabupaten Kupang kurang optimal, ini dikarenakan tidak adanya pihak/petugas yang melakukan perawatan terhadap fasilitas dan infrastruktur yang ada. Hal ini terlihat dari kerusakan pada fasilitas WC yang tidak bisa digunakan serta lopo-lopo yang 
sudah rusak total. fasilitas seperti tong sampah juga kurang diperhatikan. Akhirnya banyak ditemukan sampah yang berserakan di sekitar objek wisata.

3) Dana Yang Sangat Terbatas

Terbatasnya dana yang telah dianggarkan pemerintah

Kabupaten Kupang merupakan suatu kendala yang besar dalam pemasaran pariwisata maupun pengembangan pariwisata.

4) Kualitas Sumber Daya Manusia Yang Masih Kurang

Dalam menpersiapkan potensi ekonomi kreatif, pemerintah dan akademisi akan melakukan sejumlah pelatihan-pelatihan untuk meningkatkan kualitas dan kuantitas sumber daya manusia. Pelatihan-pelatihan yang akan dilakukan berupa tentang pengolahan rumput laut, pengolahan hasil tangkapan ikan nelayan tradisional, penangkaran ikan/bandeng, pengolahan garam tradisional, usaha penyewaan perahu, kerajinan kulit kerang dan koral. Hal ini diharapkan dapat meningkatkan ekonomi masyarakat setempat dengan ekonomi kreatif.

\section{KESIMPULAN DAN SARAN}

\section{Kesimpulan}

Berdasarkan data-data observasi pelengkap penelitian ini (yang sedang berlangsung) dan pembahasan mengenai pengembangan model ekonomi kreatif bagi masyarakat di daerah objek wisata bahari Kabupaten Kupang Nusa Tenggara Timur diperoleh kesimpulan: a. Dibutuhkan sebuah model pengembangan ekonomi kreatif yang tepat bagi Pemerintah Kabupaten Kupang dalam memajukan ekonomi kreatif bagi masyarakat di daerah objek wisata bahari.

b. Model pengembangan ekonomi kreatif yang ditawarkan dengan melibatkan semua pihak baik Pemerintah Kabupaten Kupang, pihak perbankan, pihak investor dan terutama masyarakat di daerah objek wisata dalam rangka menciptakan produk yang bersifat ekonomi kreatif.

\section{Saran}

Berdasarkan data-data observasi pelengkap penelitian ini (yang sedang berlangsung) dan kesimpulan di atas, maka dapat disarankan sebagai berikut:

a. Dengan adanya model pengembangan ekonomi kreatif diharapkan model ini dapat dijadikan sebagai sebuah rujukan bagi Pemerintah Kabupaten Kupang dapat menerapkannya sehingga mampu meningkatkan ekonomi kreatif bagi masyarakat di objek wisata bahari.

b. Bagi masyarakat di pesisir objek wisata bahari mampu meningkatkan kehidupan ekonominya melalui penciptaan produk-produk ekonomi kreatif.

c. Bagi investor dan perbankan hendaknya mampu memberikan perhatian berupa teknologi, modal usaha dan sumber daya lain bagi masyarakat/pelaku usaha ekonomi kreatif di objek wisata bahari dalam memajukan usahanya.

\section{DAFTAR PUSTAKA}

Jasman, Syofyan Siregar dan Rifardi. 2014. Strategi Pengembangan 
Ekowisata Bahari Pulau Palambak Kabupaten Aceh Singkil Provinsi Naggroe Aceh Darussalam, Jurnal Online Mahasiswa, Unri.

Karryono, A. Hari, 1997. Kepariwisataan I (Mengurai tentang istilah-istilah pariwisita sampai dengan definisi serta kebijaksanaan kinerja. Jakarta, PT. Gramedia.

Mularsih, K. Nuringsih, dan TM. Mukmin, 2014. Pemberdayaan Masyarakat Sekitar Tanjung Pasir Melalui Model Kewirausahaan Sebagai Upaya Mendukung Destinasi Wisata Pantai Tanjung Pasir. LPKMV. Universitas Tarumanegara.

Oka, A. Yoeti. 1985. Pengantar Ilmu Pariwisata. Angkasa; Bandung.

Pariwisata. Bandung: Mandar Maju.

Soekadijo. R. G. 1996. Anatomi Pariwisata. Gramedia Pustaka Utama; Bandung.

Suwantoro, Gamal. 1997. Dasar-dasar Pariwisata, Yogyakarta. Andi Offset.

Undang-undang No. 9 Tahun 1990 Tentang Pariwisata Perpu No. 4 Tahun 1994 Tentang Pariwisata 